And a French government commission, set up in 2008 to assess economic performance, is one of many attempts to account for the limitations of the gross domestic product as a measure of social progress. Such examples are evidence of the growing global dialogue on providing real solutions to the problem of building a sustainable and desirable future. A journal entitled Solutions (of which I am editor-in-chief, and Orr and Hawken are associate editors) is due to launch soon to add to these discussions.

All of this shows that a global cultural shift and transformation is indeed in progress. As Orr concludes, this transformation "has grown into a worldwide movement that rejects the idea that we are fated to end the human experiment with a bang or a whimper on a scorched and barren Earth". We still have a choice, but it is now or never. Orr's book will do much to help achieve the required cultural transformation, hopefully just in time.

Robert Costanza is director of the Gund Institute for Ecological Economics at the University of Vermont, Burlington, Vermont 05405, USA. e-mail: robert.costanza@uvm.edu

\title{
The wider lessons for finance
}

One of the unintended effects of the nearcollapse of the world economy is the creation of a market for scientific advice to the banking sector. Senior officials at the Bank of England, for example, are consulting the theoretical ecologist and former Royal Society president Robert May, whose research interests include modelling ecosystem collapses and the spread of infectious diseases. Why? Because May's work could provide signposts on how to develop a comprehensive model for the movement of money around the world and the myriad connections between cash, individuals and institutions.

Two books highlight insights from other fields, such as psychology and anthropology, on the current global financial situation, and the damage done in the past by inappropriately applied mathematics. They also suggest that finance can learn even greater lessons from science, by taking account of the experiences of scientists and science's ideal of transparency and regulation.

In Animal Spirits, two Keynesian economists - George Akerlof, a Nobel-prizewinning economist at the University of California, Berkeley, and Robert Shiller, an economist at Yale University - use findings from psychology to amplify one of economist John Maynard Keynes's theories. In his signature 1936 work, The General Theory of Employment, Interest and Money, Keynes explained that economies should fluctuate because people behave in unpredictable ways - under the influence of what he called "animal spirits".

Keynes's theory countered the mainstream view in economics that people, and therefore markets, behave in rational ways. But people often decide which house to buy or which car to drive because it 'feels right', or for other reasons that economists may find irrational or cannot measure accurately. Akerlof and Shiller remind us that emotional and intangible factors - such as confidence in institutions, illusions about the nature of money or a sense of being treated unfairly - can affect how people make decisions about borrowing, spending, saving and investing.

Animal Spirits is an affectionate tribute to the man whose ideas, unfashionable for the past 30 years, have resurged. Having advised governments through the Depression, Keynes became convinced that more government spending was needed to maintain employment during a recession - a prescription that has been adopted by many national leaders, including UK Prime Minister Gordon Brown and US President Barack Obama.

What Animal Spirits doesn't do is illustrate how descriptions of human behaviour can be used in quantitative financial and economic models. Bankers, analysts and policy-makers reading the book will want to know where they can find data on human behaviour, and how these data can be reduced to the indices, constants and variables that make up their equations. Akerlof and Shiller would have done well to have included a chapter covering this issue.

Insights from science have the potential to be misused, however. Gillian Tett's book Fool's Gold is an exceptional account of how today's financial world became in thrall to advanced mathematics. Tett, who runs the coverage of global markets for the Financial Times newspaper, came to journalism after taking a doctorate in social anthropology. Her book describes how a small group of young bankers with training in mathematics, physics and actuarial science created a class of financial products known as credit derivatives, the misuse of which helped to precipitate today's crisis.

Tett recounts how a group at J. P. Morgan, one of the United States' oldest commercial banks, came up with a scheme designed to free up more of the bank's capital for profitmaking investment: selling the loans on their books to third-party buyers. The regulators were unsure whether this was allowed, but Tett shows how they were eventually won over following an aggressive lobbying campaign led by the bank.

Interestingly, J. P. Morgan decided not to shift bundles of mortgage loans in the same way as they were selling off commercial loans. This is because the bank did not have enough data to accurately predict the numbers of borrowers who would default, or the extent to which one defaulter might trigger others. Other banks, however, began to offer bundles of individual mortgages - including those given to 'sub-prime' clients. This practice was helped along by David Li, an actuarial scientist who published a formula that claimed to predict patterns of defaulting without needing data on individual financial histories. The market for sub-prime loan bundles went through the roof, and when these sub-prime borrowers began to default, the world economy went through the floor.

Tett concludes that banking needs to go back to an earlier philosophy: products should be simple to understand, bankers need to respect the fact that regulators are acting in the public interest, and regulators need to be more on the ball. This checklist sounds like the regulatory hurdles that many scientists have experience of - especially those working in areas such as food safety and environmental protection.

For example, after the bovine spongiform encephalopathy ('mad cow') epidemic and controversies over genetically modified crops in the 1990s, there was much soul-searching in Britain over how best to protect the public from possible future harm. One outcome was 
a new food-standards agency, independent of government and industry, to act in the interests of consumers. Many scientists were not enthusiastic about this change. But those who have worked in the system realize that good regulation and transparency are not enemies of progress.

The banking industry is waking up to the fact that advanced knowledge helped to create profits beyond imagination, but that greed and secrecy played a part in its neardownfall. Animal Spirits gives hope that such knowledge can be a force for good. Fool's Gold, meanwhile, reminds us that this must go hand-in-hand with transparency and keeping the public interest uppermost.
Ehsan Masood teaches international science policy at Imperial College London. e-mail:em@ehsanmasood.com

\section{Ehsan Masood will chair a Nature debate on science and the financial crisis in London on 21 September - details at http://tinyurl.com/nc9pvn. For more on the economy, see http://tinyurl.com/nlb76n.}

\section{How Spain redrew the world}

\section{Secret Science: Spanish Cosmography and the New World \\ by María M. Portuondo \\ University of Chicago Press: 2009 \\ 360 pp. $\$ 45$}

In the autumn of 1571, Juan López de Velasco, an ambitious legal scholar with one eye on the heavens, accepted the coveted position of chief cosmographer and chronicler to Philip II, the King of Spain. Velasco received a salary hike and a trunk filled with invaluable documents collected by his predecessor. In the years that followed, the maps, treatises and narrative accounts found inside the trunk revealed the geography of a new world to this enthusiastic map-maker, whose job included updating the empire's navigational charts and keeping ships' pilots and government bureaucrats informed of any new geographical data retrieved from overseas. Velasco sat at the centre of one of the most successful information-gathering operations the world had ever known. But his work remained secret for centuries.

Thanks to several recent studies, the private knowledge held by generations of servants to the Iberian Crown - and hidden for centuries in musty archives - has now been thrust into the public eye. One such study is María Portuondo's impeccably researched book on Spanish cosmographical practice. Cosmography was a discipline that involved creating textual descriptions of the known world using charts and images similar to those bequeathed to Velasco. The early modern equivalent of satellite-enhanced telemetry, these colourful cartographic images served sixteenth-century monarchs and their ministers in pragmatic ways. They were used for plotting trade routes, tracing the design of new cities, conceiving military campaigns and imagining the world's emerging political boundaries.
At stake in these materials was the very nature of scientific practice itself. Long before Galileo Galilei cast doubt on the existence of an Earth-centred Universe, Spanish navigators and royal cosmographers were already working to overturn centuries of received wisdom about the layout of the cosmos and Earth's place within it. Science, and the direction of the modern world, would never be the same.

Cosmography was Renaissance shorthand for several modern disciplines: astronomy, history, geography, anthropology, navigation and the study of nature. Practitioners brought together these techniques with the classical

New World and a crescendo of reports from Spanish pilots heralding islands and continents that were previously unknown, cosmographers had to quickly adjust the master chart of the world, held at the House of Trade in Seville, Spain's central clearing house for geographical information. Eyewitness observations from the Americas would trump ancient theories as the world map was redrawn.

In the past two decades or so, some Spanish historians of science have adopted a defensive tone when discussing the supposed lack of Iberian prowess during the scientific revolution as compared with the better-known discoveries made by northern Europeans such as Francis Bacon, Johannes Kepler or Isaac Newton. They argue that Spanish and sometimes Portuguese navigators were precursors to those 'revolutionary' scientific activities. Spanish pursuits in astronomy, navigation and other empirical disciplines, they assert, have historically been neglected or ignored owing to long-standing prejudice and misinformation.

Particularly refreshing in Portuondo's tale is the absence of such an attitude. Rather, she shows how a cast of eclectic men of letters in service to the Spanish crown set out to change the image of the world. They developed elaborate geographical questionnaires to learn from local populations, and sponsored programmes of celestial observations - during lunar eclipses, for instance - to make a global network of field laboratories out of their monarch's territorial

and biblical narratives describing the shape of the known world, which, at the time, stretched barely beyond the African coast and Asia minor - as described by influential geographers such as the Greek Strabo and the Roman Pomponius Mela.

But in 1492 everything changed. Once Spanish galleons had crossed the Atlantic under the command of the Genoese navigator Christopher Columbus, Spanish cosmographers were forced to reconcile increasingly contradictory ways of thinking. With the discovery of the possessions, even though the results were never publicized beyond a privileged few.

Similarly to Velasco's chest of cartographic treasures, Portuondo's study reveals valuable evidence with which scholars can refashion their images of the Renaissance world and the achievements of Spanish science at the dawn of modernity.

Neil Safier teaches history at the University of British Columbia, Vancouver V6T 1Z1, Canada, and is author of Measuring the New World. e-mail: neil.safier@ubc.ca 